\section{Magdalena Dąbrowska}

Uniwersytet

Marii Curie-Skłodowskiej

w Lublinie

\title{
Próba pasienia kotów, czyli intelektualny krajobraz animal studies
}

\section{Abstract \\ Herding Cats: The Intellectual Landscape of Animal Studies}

Mapping animal studies I present three main approaches: studies of human-animal relationships, critical animal studies and research inspired by posthumanism. They analyze animals from various perspectives, using different theories and research methodologies. Despite major differences they are based on the assumption that animals should be treated as subjects. Moreover, academic research is supposed to influence the social practices and attitudes towards animals. The relationships between animal studies and activism and between academic research and activism are also analyzed.

Słowa kluczowe: animal studies, badanie relacji człowiek-zwierzę, krytyczne studia nad zwierzętami, posthumanizm

Keywords: animal studies, human-animal studies, critical animal studies, posthumanism 
Cary Wolfe wyraża się żartobliwie o wysiłkach zmierzających do usystematyzowania dynamicznie rozwijających się studiów nad zwierzętami, nazywając je próbą ,pasienia kotów”'. W wypadku wszelkich nowych dyscyplin impet twórczy i zachwyt nad otwierającymi się możliwościami sprawia, że dociekania rozwijają się w wielu kierunkach. Na zwierzęta natkniemy się w każdej dziedzinie kultury. Pojawiają się one jako metafory, występują w przysłowiach, utworach literackich i filmach, są przedmiotem sztuki, filozofii, badań historycznych oraz regulacji prawnych. Konsekwencją tej wieloznaczności i wielowymiarowości jest dynamicznie rozwijający się obszar badań. Dodatkowo „zmącenie gatunków”, charakterystyczne dla postmodernistycznego stanu wiedzy, nie ułatwia prowadzenia klasyfikacji. W studiach nad zwierzętami można wyróżnić kilka głównych nurtów, a także mniejszych odgałęzień, które nie dają się jednoznacznie uporządkować. Z powodu swojej złożoności, wielodyscyplinarności i wielości perspektyw obszar ten podobny jest raczej do „kłącza” niż do „drzewa”.

Pierwsze publikacje na temat relacji człowiek-zwierzę dotyczyły filozofii i etyki. Dociekania filozoficzne wywarły znaczny wpływ na rozwój ruchu na rzecz praw zwierząt. Publikacja w Stanach Zjednoczonych książki Petera Singera Wyzwolenie zwierzat (1975), a następnie The Case for Animal Rights Toma Regana (1983) spowodowały zainteresowanie tematyką zwierzęcą w środowiskach akademickich, na gruncie nauk społecznych, psychologii, socjologii czy antropologii ${ }^{2}$. Prowadzone badania empirycznie dowiodły olbrzymiego wpływu relacji ze zwierzętami na życie ludzi oraz pomogły zidentyfikować zróżnicowanie tych wpływów. Powstałe w 1987 roku czasopismo „Anthrozoös, Society \& Animals” czy najnowsze „Humanimalia” (2009) umożliwiały prowadzenie dyskusji na znaczące dla rozwoju dyscypliny tematy. W latach 90. ubiegłego wieku pod wpływem postmodernizmu i posthumanizmu także nauki humanistyczne zainteresowały się tematyką zwierzęcą, kwestionując binarne opozycje, takie jak człowiek-zwierzę czy kultura-natura. Istnienie tych podziałów to jeden z kulturowych fundamentów, na których oparty jest status zwierząt.

Zwierzęta są nie tylko przedmiotem debat akademickich. Zainteresowanie ekologią, ochroną, warunkami hodowli oraz dobrostanem zwierząt znajduje oddźwięk w aktach legislacyjnych i staje się przedmiotem politycznych debat. Troska o dobrostan pojawia się nawet $\mathrm{w}$ deklaracjach międzynarodowych koncernów (odejście od sprzedaży jajek z chowu klatkowego), co jest reakcją na zmieniające się wartości konsumentów. Wegetarianizm i weganizm stają się stylami życia popularnymi wśród osób wrażliwych na krzywdę zwierząt,

1 C. Wolfe, Human, All too Human: „Animal Studies” and the Humanities, „PMLA” 2009, vol. 124, no. 2, s. 564.

2 Zob. K. Shapiro, M. DeMello, The State of Human-Animal Studies, „Society and Animals" 2010, no. 18 (3). 
dbających o zdrowie i zainteresowanych kondycją planety. Emocjonalne więzi tworzone z domowymi ulubieńcami znajdują odzwierciedlenie w rosnącym rynku produktów i usług.

Cary Wolfe podkreśla dwa istotne aspekty animal studies. Po pierwsze, zajmują się one rzeczywistymi zwierzętami, a także analizują dyskursy tworzące i podtrzymujące różnice pomiędzy ludźmi a nie-ludźmi. Po drugie, uprawianie tej dyscypliny nie jest związane z miłością do zwierząt. Zainteresowanie dziedziną często rozpoczyna się od osobistego doświadczenia bliskości lub empatycznego współczucia dla ich cierpienia, analizy wykraczają jednak poza sentymentalną sympatię. Zadaniem jest dotarcie do kulturowych fundamentów sposobu reprezentacji zwierząt, ich rozchwianie i zdekonstruowanie.

Zdaniem Wolfe'a animal studies różnią się od innych badań humanistycznych czy społecznych dotyczących zwierząt przedmiotem wiedzy oraz podejściem teoretycznym i metodologicznym ${ }^{3}$. Zajmowanie się tą tematyką w tradycyjnych badaniach akademickich nie oznacza wyzbycia się antropocentryzmu. Niejednokrotnie zwierzęta są tam traktowane jak przedmioty i analizowane wyłącznie z punktu widzenia ich użyteczności dla człowieka. Animal studies opierają się natomiast na założeniach teoretycznych i metodologicznych, których podstawowym celem jest podważenie uprzywilejowanej pozycji poznawczej ludzkiego podmiotu oraz antropocentrycznej perspektywy opisywania rzeczywistości. Ma się to przełożyć na zmiany w mentalności i ustawodawstwie, które wpłyną na postrzeganie pozycji i roli zwierząt w kulturze i społeczeństwie ${ }^{4}$.

W animal studies antropocentryzm, a także sposób tworzenia wiedzy, która opiera się wyłącznie na ludzkiej perspektywie i doświadczeniu, poddane są ostrej krytyce. Antropocentryzm nie tylko wpływa na sposób tworzenia wiedzy, ale także uzasadnia praktyki, które są okrutne i moralnie nieuzasadnione, ale przydatne dla człowieka (przemysłowa hodowla zwierząt czy eksperymenty medyczne). W animal studies antropocentryzm bywa też zastępowany przez ekocentryzm ${ }^{5}$. Nawiązuje się do ekologii głębokiej, podkreśla istnienie zależności w ramach ekosystemów oraz rolę powiązań między różnymi formami życia. Natura jest wartością samą w sobie, niezależnie od tego, jak realizuje ludzkie interesy.

Tradycyjnie granica między człowiekiem a zwierzęciem opierała się na przekonaniu o wyjątkowości ludzi. Dowodzono, że wyłącznie człowiek posiada duszę, potrafi myśleć, mówić, wyrażać emocje czy odczuwać cierpienie. Tradycja kartezjańska traktowała zwierzęta jako przedmioty pozbawione umiejętności myślenia, a przez to nieodczuwające bólu. Większość nauk przyrodniczych definiuje je jako radykalnie różne (metafizycznie) od ludzi.

3 C. Wolfe, Human, All too Human..., s. 568.

4 Zob. ibidem.

5 Zob. N. Taylor, Humans, Animals, and Society: An Introduction to Human-Animal Studies, New York 2013. 
Animal studies odrzucają przekonanie o ludzkiej wyjątkowości; przyjmują, że zwierzęta to społecznie konstruowane byty pod wieloma względami podobne do człowieka.

Obecnie różnica między naukami przyrodniczymi a animal studies nie jest jednoznaczna. Takie dyscypliny, jak etologia kognitywna czy prymatologia, mimo iż osadzone $\mathrm{w}$ paradygmacie przyrodniczym, opisują zwierzęta jako myślące i czujące istoty społeczne ${ }^{6}$. Najnowsze badania genomu wskazują na znaczne podobieństwa między ludźmi a innymi gatunkami. Psychologia międzygatunkowa stara się zrozumieć zwierzęta oraz to, jaki sens nadają one relacjom tworzonym z ludźmi. Założenie o podobieństwach w sposobie doświadczania świata podważa fundamenty ludzkiej wyjątkowości.

Jednym ze sposobów poznawania zwierząt jest analiza sposobu ich przedstawiania w kulturze masowej, wizualnej czy w mediach społecznościowych. Niektóre gatunki stereotypowo ukazywane są jako agresywne i złe (rekiny, wilki), co może wpływać na sposób ich traktowania (np. przyzwolenie na zabijanie). Filmy przyrodnicze w znaczący sposób kształtują nasze rozumienie „natury”, a tworzone przez nie narracje o życiu zwierząt często oparte są na antropomorfizacji. Proces przekształcania zwierząt w społeczne i kulturowe symbole stanowi jeden $\mathrm{z}$ aspektów analizy w animal studies.

„Zwierzęta” podobne są do innych konstruktów społecznych, takich jak płeć, rasa czy seksualność. Kategorie te mogą się wydawać zakorzenione w biologii (pozornie czymś obiektywnym i niezmiennym), ale w rzeczywistości to kategorie zdefiniowane przez kulturę, a ich znaczenie nadawane jest w trakcie społecznych praktyk. Nik Taylor stwierdza: „,zwierzęta są społecznie konstruowane i składają się ze znaczeń zapośredniczonych przez kulturę"7. Różnica między człowiekiem i zwierzęciem może być zakorzeniona w różnicy biologicznej, większość ludzi czerpie jednak wiedzę z kulturowych reprezentacji, wierzeń (także religijnych) i społecznie akceptowanych praktyk. Przekonanie to wywarło olbrzymi wpływ na definiowanie obszaru zainteresowań dyscypliny. Susan McHugh definiuje zatem animal studies jako „interdyscyplinarny obszar badań skupiony na kwestiach podmiotowości i tego, co społeczne, podkreślający, że sposób odczytywania zwierzęcych reprezentacji odbywa się pod wpływem aksjologicznych i innych »nienaturalnych» historii"

W animal studies można wyróżnić trzy główne podejścia: badania relacji człowiek-zwierzę, krytyczne studia nad zwierzętami oraz nurt inspirowany

6 K.W. Benston, Experimenting at the Threshold: Sacrifice, Anthropomorphism, and the Aims of (Critical) Animal Studies, „PMLA” 2009, no. 124 (2), s. 548.

7 N. Taylor, op.cit., b.s. (plik epub).

8 S. McHugh, One or Several Literary Animal Studies?, H-Animals, H-Net, 2006, https://networks.h-net.org/node/16560/pages/32231/one-or-several-literary-animal-studies-susan-mchugh [dostęp: 15.01.2018]. 
posthumanizmem. Poszczególne nurty różnią się założeniami teoretycznymi i ideowymi, przedmiotem zainteresowania oraz metodami badawczymi. Łączy je przekonanie, iż zwierzęta należy traktować w sposób podmiotowy, a badania powinny (pośrednio lub bezpośrednio) wywierać wpływ na praktyki wobec zwierząt w kulturze. Rosnąca popularność animal studies widoczna jest także w Polsce. Pojawiają się konferencje i czasopisma (,Zoophilologica") poświęcone wyłącznie tej tematyce. Podejmując się próby naszkicowania „mapy” studiów nad zwierzętami, zajmuję się głównie badaniami prowadzonymi w krajach anglosaskich, gdyż polskie animal studies nie wykształciły jeszcze własnych oryginalnych podejść czy metodologii.

\section{Badanie relacji człowiek-zwierzę (Human-Animal Studies)}

Badanie relacji człowiek-zwierzę (Human-Animal Studies, w skrócie HAS), zwane także antrozoologią (anthrozoology), to zróżnicowane tematycznie i metodologicznie dociekania na temat naszych relacji ze zwierzętami. Istniejące badania obejmują różne zagadnienia, lecz wszystkie podkreślają złożony charakter tej relacji. Kontakty ze zwierzętami są niezbywalną częścią ludzkiej kultury, wywierają wpływ na życie jednostek, tworząc trwałe i silnie nacechowane emocjami więzi z opiekunami. Zwierzęta, wcześniej sytuowane na zewnątrz społeczeństwa i kultury, stają się integralną część obu tych sfer. O ile paradygmat kartezjański zbudowany był na przekonaniu o nieusuwalnych różnicach między człowiekiem a zwierzęciem, o tyle badacze HAS opierają się na wywodzącym się z darwinizmu poglądzie o fizycznej i psychicznej ciągłości, przekonując, że różnica między ludźmi a zwierzętami jest raczej różnicą stopnia, a nie rodzaju. Nasza tożsamość tworzy się przez interakcje z innymi gatunkami; to dzięki zwierzętom stajemy się ludźmi. Sposób tworzenia tożsamości w międzygatunkowych powiązaniach jest przedmiotem dociekań w posthuman studies, ale HAS tworzą fundament dla tych badań.

Relacje ludzi ze zwierzętami są złożone i mogą przybierać różnorodne formy: od miłości po przemoc. Zależy to nie tylko od indywidualnych cech jednostki, ale także wynika $\mathrm{z}$ kulturowych różnic w postrzeganiu różnych gatunków zwierząt. Dwie powszechne praktyki: troska o domowych ulubieńców oraz spożywanie mięsa, ukazują radykalnie odmienne formy relacji. Pomiędzy tymi dwoma przeciwnymi biegunami znajdziemy cały wachlarz postaw. Istotne, że badania obejmują zarówno kulturowe reprezentacje i praktyki społeczne, jak i odnoszą się do rzeczywistych zwierzęt. Zwierzę nie jest wyłącznie teoretycznym konceptem, ale fizycznym, odczuwającym ciałem.

Popularnym tematem badań są relacje człowiek-zwierzę w takich instytucjach, jak laboratoria, schroniska, kliniki weterynaryjne, rzeźnie, ośrodki szkolenia psów. Clinton Sanders analizował stosunki między psami policyj- 
nymi a ich opiekunami ${ }^{9}$. Leslie Irvine badała tworzenie się relacji miłości w schroniskach dla zwierząt, a także więź między osobami bezdomnymi a ich psami ${ }^{10}$, Harold Herzog zaś zajmował się związkami między ludźmi a ich zwierzętami towarzyszącymi ${ }^{11}$. James Serpell analizował tę problematykę w kontekście historycznym ${ }^{12}$. Istnieją także dowody na korzystny wpływ relacji ze zwierzętami na zdrowie i samopoczucie ludzi ${ }^{13}$. Wzrost zainteresowania programami terapeutycznymi z udziałem zwierząt oraz kwestią ich dobrostanu, a także pojawienie się nowych dziedzin badań, takich jak psychologia międzygatunkowa, świadczą o zmianie naszego sposobu myślenia.

HAS analizuje również społecznie akceptowane praktyki w takich instytucjach, jak rzeźnie, laboratoria czy hodowle przemysłowe. Negatywny wymiar relacji ze zwierzętami obejmuje różne formy przemocy. Zwierzęta padają ofiarami przemocy domowej (podobnie jak mężczyźni, kobiety i dzieci), a także masowo doświadczają przemocy w laboratoriach, farmach czy rzeźniach. HAS stara się poznać zarówno doświadczenia ludzi stosujących przemoc, jak i jej wpływ na zwierzęta. Poznanie behawioralnych, psychicznych i emocjonalnych potrzeb zwierząt pozwala rozszerzyć wiedzę na temat ich dobrostanu. Wyniki badań coraz częściej są wykorzystywane $\mathrm{w}$ farmach hodowlanych, a nawet w rzeźniach, w celu zmiany stosowanych tam praktyk. Można żywić nadzieję, że badania te nie tylko posłużą do zmiany warunków hodowli, ale także w przyszłości przyczynią się do zakończenia wszelkich form eksploatacji.

Kenneth Shapiro za jedno z fundamentalnych założeń HAS uznaje ,szacunek dla zwierząt innych niż ludzie i traktowanie ich jak bytów obdarzonych własnym doświadczeniem i interesami, a nie wyłącznie jak kulturowych artefaktów, symboli, modeli czy rzeczy w świecie skoncentrowanym na ludziach"14. Podejście takie zapewni zwierzętom miejsce w naszym „moralnym krajobrazie”. Badanie relacji człowiek-zwierzę (HAS) obejmuje okreś-

9 Zob. C. Sanders, „The Dog You Deserve”: Ambivalence in the K-9 Officer/Patrol Dog Relationship, ,Journal of Contemporary Ethnography” 2006, no 35 (2).

10 Zob. L. Irvine, If You Tame Me: Understanding our Connection with Animals, Philadelphia 2004.

11 Zob. H. Herzog, Gender Differences in Human-Animal Interactions: A Review, „Anthrozoös” 2007, no. 20 (1); idem, Some We Love, Some We Hate, Some We Eat: Why It's So Hard to Think Straight About Animals, New York 2010.

12 Zob. J. Serpell, W towarzystwie zwierząt. Analiza związków ludzie-zwierzęta, przeł. A. Alichniewicz, Warszawa 1999.

13 Zob. A. Beck, A. Katcher, Between Pets and People: The Importance of Animal Companionship, Indiana 1996.

14 K. Shapiro, The State of Human-Animal Studies: Solid, at the Margin!, „Society and Animals" 2002, no. 10 (4), s. 332-333. 
loną problematykę, a także opiera się na konkretnych założeniach etycznych i ideologicznych. Podkreśla się konieczność rozwijania oryginalnej metodologii i teorii badań, umożliwiającej realizację założeń ideowych HAS.

Shapiro z jednej strony zwraca uwagę, że nie wszystkie badania podejmujące temat zwierząt można zaliczyć do HAS, i podaje przykładowe zagadnienia, które wprawdzie dotyczą zwierząt, ale nie spełniają założeń ideowych ${ }^{15}$. Badania etologiczne nie mieszczą się w HAS, można jednak wykorzystywać ich wyniki do analizy istniejących lub możliwych relacji człowiek-zwierzę. Antropologiczne badania znaczenia gatunków udomowionych w ekonomii danej społeczności nie spełniają założeń HAS, gdyż traktują zwierzęta jak towary. $Z$ drugiej strony wiele relacji ludzi ze zwierzętami opiera się na utowarowieniu, dlatego wyniki takich badań mogą okazać się przydatne. Literackie badania zwierząt jako metafor ludzkich wad i zaleta ograniczają się do tekstów literackich, więc mogą być obarczone antropocentryzmem. Jeśli jednak naświetlają mnogość relacji ze zwierzętami w naszej kulturze, mogą stać się częścią HAS. Kliniczne badania osób poddanych leczeniu z wykorzystaniem zwierząt-terapeutów (zooterapia) koncentrujące się wyłącznie na ludziach, nie są częścią HAS. Jeśli jednak biorą pod uwagę także doświadczenia zwierzęcia oraz starają się oszacować wpływ takiej pracy na jego dobrostan, spełniają wymagania stawianie przed badaczami relacji człowiek-zwierzę.

Analizując sytuację studiów nad relacjami człowiek-zwierzę, Shapiro i DeMello zwracają uwagę na problemy, takie jak antropocentryzm i konserwatyzm akademii oraz międzydyscyplinarny charakter studiów, pociągający za sobą trudności z umiejscowieniem ich wewnątrz dyscyplin akademckich ${ }^{16}$. Funkcjonowanie HAS w obrębie różnych dziedzin wiedzy wskazuje na wielość perspektyw, z jakich zagadnienia te mogą być analizowane. Łączenie wiedzy z zakresu nauk przyrodniczych i społecznych jest bardzo częste, rodzi to jednak problemy z jednoznacznym zakwalifikowaniem badań do wąskich dyscyplin naukowych, co może być przeszkodą w tworzeniu kursów akademickich czy w ubieganiu się o granty badawcze. Shapiro i DeMello zwracają także uwagę na tarcia wynikające z prób łączenia pracy akademickiej z działalnością na rzecz praw zwierząt. W odróżnieniu od aktywistycznie nastawionych przedstawicieli krytycznych studiów nad zwierzętami badacze zajmujący się relacjami człowiek-zwierzę nie zawsze łączą praktykę akademicką $\mathrm{z}$ działaniami na rzecz właściwego traktowania zwierzą ${ }^{17}$.

\footnotetext{
15 Ibidem.

${ }^{16}$ Zob. K. Shapiro, M. DeMello, op.cit.

17 Zob. ibidem.
} 


\section{Krytyczne studia nad zwierzętami (Critical Animal Studies)}

Krytyczne studia nad zwierzętami (Critical Animal Studies, w skrócie CAS) to nurt badawczy powiązany z powstałym w 2001 roku Institute for Critical Animal Studies (ICAS). Celem ICAS jest prowadzenie studiów krytycznych, co wynika z przekonania, że relacje ludzi ze zwierzętami przeżywają kryzys, który osiąga rozmiary planetarnej katastrofy. Przemysłowa hodowla oraz masowa rzeź zwierząt, zagłada kolejnych gatunków, globalne ocieplenie, wycinka lasów tropikalnych, zanieczyszczenie wody i środowiska itp. są powiązane ze sposobem traktowania zwierząt $\mathrm{w}$ naszej kulturze, a także $\mathrm{z}$ innymi negatywnymi zjawiskami i procesami. Badaczki ekofeministyczne już w latach 70 . $\mathrm{XX}$ wieku zwracały uwagę na związki między traktowaniem kobiet i natury w patriarchalno-kapitalistycznym społeczeństwie. Istnieją również powiązania między podejściem do zwierząt $\mathrm{w}$ nowoczesnej kapitalistycznej gospodarce a innymi systemami opresji, takimi jak seksizm czy rasizm. Do teoretycznych inspiracji CAS można też zaliczyć krytyczną myśl szkoły frankfurckiej, krytykę społeczeństwa kapitalistycznego oraz posthumanizm.

Istnieje kilka założeń definiujących specyfikę $\mathrm{CAS}^{18}$. Krytyczne studia nad zwierzętami to interdyscyplinarne badania włączające perspektywy zazwyczaj ignorowane przez studia nad zwierzętami, np. ekonomię polityczną. Odrzucają one pseudoneutralność analiz akademickich i otwarcie przyznają się do konkretnego systemu wartości i politycznego zaangażowania. Teoria nigdy nie jest oderwana od praktyki, a badania nie są apolityczne. Przedstawiciele CAS odrzucają czystą teorię na rzecz powiązania teorii z praktyką, analizy z polityką, a badaczek (badaczy) ze wspólnotą. Przyjmują całościowe rozumienie opresji i traktują gatunkowizm, seksizm, rasizm, dyskryminację osób niepełnosprawnych, władzę państwa, system klasowy, militaryzm i inne ideologie oparte na hierarchiach jako część globalnego systemu dominacji. Promują antykapitalistyczną i antyhierarchiczną politykę, mającą na celu rozbicie wszystkich struktur dominacji i wyzysku oraz decentralizację i demokratyzację społeczeństwa na wszystkich poziomach. Odrzucają reformistyczne, skoncentrowane na jednym problemie działania legislacyjne na rzecz szerokich sojuszy mających znieść opresję i hierarchie. Podkreślają powiązanie wolności ludzkiej z wyzwoleniem ziemi i zwierząt. Usiłują znieść binarne różnice między ludźmi a zwierzętami, a także takie dychotomie, jak natura-kultura czy cywilizacja-dzikość. Postulatowi wyzwolenia natury towarzyszy projekt zniesienia granic, którego celem jest pokój, wolność i ekologiczna harmonia. Przedstawiciele CAS mają na celu stworzenie przestrzeni do konstruktywnego i krytycznego dialogu między akademiczkami, obywatelkami, działaczkami

18 Zob. S. Best, A.J. Nocella II, C. Gigliotti, L. Kemmerer, Introducing Critical Animal Studies, ,Journal for Critical Animal Studies” 2007, no. 5 (1); D. McCance, Critical Animal Studies: An Introduction, Albany 2013. 
społecznymi, pracownicami organizacji publicznych i politycznych itp. Wierzą, że przez ekopedagogikę i współpracę z różnymi ruchami społecznymi można stworzyć nowe formy świadomości, wiedzy oraz instytucje społeczne.

CAS jest podejściem bardziej radykalnym i politycznie zaangażowanym niż Human-Animal Studies. Jego reprezentanci aktywnie działają na rzecz praw zwierząt, ekologii i zmiany systemu ekonomiczno-społecznego. Teoria zespolona jest z praktyką, czego wyrazem staje się styl życia zrywający z eksploatacją zwierząt. Weganizm jest bardzo popularny, a podczas konferencji nie serwuje się posiłków zawierających produkty zwierzęce. Łączy się to z przekonaniem, że nie można prowadzić krytycznych badań poświęconych zwierzętom, nie troszcząc się jednocześnie o ich los.

Badania CAS inspirowane są różnymi nurtami marksizmu. Wiąże się to z przekonaniem, że kapitalizm odpowiedzialny jest za większość form opresji widocznych we współczesnym społeczeństwie. Pogoń za zyskiem łączy się z eksploatacją przyrody oraz okrutnymi praktykami wobec zwierząt (przemysłowa hodowla i eksperymenty na zwierzętach są tego najbardziej drastycznym przykładem).

Krytyczne studia nad zwierzętami koncentrują się w szczególności na kilku zagadnieniach: eksperymentach na zwierzętach, przemysłowej hodowli i zabijaniu zwierząt oraz ogrodach zoologicznych. Są to obszary, w których liczba nadużyć i przemocy wobec zwierząt jest największa. Cel CAS stanowi zbadanie tych obszarów, a także zaproponowanie nowych rozwiązań politycznych i prawnych regulujących relacje między ludźmi a zwierzętami. Mają one brać pod uwagę interesy zwierząt oraz ich prawa ${ }^{19}$. Krytyczne studia nad zwierzętami dążą do destabilizacji takich pojęć, jak „człowiek” czy „,zwierzę”, aby dzięki temu powrócić do ontologicznych pytań o zakres władzy, jaką ludzie mogą sprawować nad innymi formami życia. CAS krytycznie rozważa okoliczności, w jakich może dojść do rzeczywistych przemian społecznych i zmiany świadomości, co wiąże się z nowym rozumieniem podmiotu, jego ucieleśnienia i emancypacji, a także z odrzuceniem dualistycznego i hierarchicznego myślenia. Czerpie inspiracje z posthumanizmu, odrzucając antropocentryczną perspektywę i powstałe na gruncie humanizmu koncepcje, które wyznaczają ramy dotychczasowych sposobów budowania relacji ze światem.

19 K.W. Benston, op.cit., s. 553. 


\section{Wpływ posthumanizmu}

Postmodernizm i posthumanizm wywarły istotny wpływ na rozwój studiów nad zwierzętami i badania relacji człowiek-zwierzę ${ }^{20}$. Krytyka kultury i epistemologii podejmowana $\mathrm{w}$ postmodernizmie ugruntowała przekonanie, że wiedza jest wytworem społecznym i odzwierciedla interesy klasy dominującej. Perspektywa ta pozwoliła z kolei na krytyczną analizę sposobów tworzenia zwierzęcości oraz społecznych praktyk dotyczących zwierząt. Badanie dyskursów i form reprezentacji zwierząt (w kulturze, sztuce, mediach itp.) stanowi istotny element tych rozważań, umożliwiając m.in. zrozumienie kulturowych fundamentów praktyk wobec zwierząt.

Posthumanizm, zróżnicowany nurt myślenia wyłaniający się we współczesnej humanistyce, krytycznie rozprawia się z usytuowaniem „człowieka” jako uprzywilejowanego bytu, jakościowo odmiennego od zwierzą ${ }^{21}$. Rosi Braidotti wskazuje na konieczność ponownego przemyślenia koncepcji człowieczeństwa ${ }^{22}$. Pokazuje, że była ona zmienna historycznie, ukształtowana raczej przez procesy społeczne i kulturowe niż biologię (przynależność do gatunku homo sapiens). W jej opinii kondycja postludzka stanowi jakościową zmianę w myśleniu o człowieku oraz konieczność stworzenia nowych koncepcji polityki i tożsamości w zglobalizowanym, opartym na technologii świecie.

Cary Wolfe definiuje postczłowieczeństwo jako wyjście poza humanizm, czyli pewną tradycję w myśleniu o świecie i człowieku, która wywarła decydujący wpływ na kształt naszej kultury, społeczeństwa i instytucji politycznych ${ }^{23}$. W jego opinii przedrostek ,post-" nie służy do określenia linearnej chronologii ani nie ma na celu zaznaczenia najnowszego trendu czy mody w humanistyce. W odległych historycznie epokach możemy znaleźć więcej inspiracji i podobieństw dla posthumanistycznego myślenia niż w naznaczonych piętnem humanizmu czasach nowożytnych. Zdaniem Wolfa takie pojęcia, jak „,człowiek” czy „zwierzę”, są reliktem humanistycznego myślenia i służą do ukrycia złożoności i wielowymiarowości naszej kondycji ${ }^{24}$. Sprawiają, że ludzka egzystencja bywa postrzegana jako odrębna i niezależna od świata zwierząt, podczas gdy w rzeczywistości nasze życie na różne sposoby jest połączone $\mathrm{z}$ istnieniem innych gatunków.

Posthumanizm problematyzuje, destabilizuje i dekonstruuje takie pojęcia, jak ,człowiek” czy „zwierzę”. Człowiek nie jest pod żadnym względem wy-

20 Zob. N. Taylor, op.cit.

21 L. Hamilton, N. Taylor, Ethnography after Humanism: Power, Politics and Method in Multi-Species Research, London 2017, s. 2.

22 R. Braidotti, Po czlowieku, przeł. J. Bednarek, A. Kowalczyk, Warszawa 2014.

23 C. Wolfe, Moving Forward, Kicking Back: The Animal Turn, „Postmedieval: A Journal of Medieval Cultural Studies" 2011, no. 2.

24 Ibidem, s. 3. 
jątkowy, okazuje się jednym $\mathrm{z}$ wielu zwierząt, innym pośród innych. Teoria aktora-sieci (ANT), stworzona przez Brunona Latoura, głosi, że ludzie, zwierzęta i materialne obiekty funkcjonują wspólnie w sieci, tworząc znaczące powiązania. Teoria postkolonialna oraz (eko)feminizm mówią z kolei o konieczności oddania głosu Innym: wykluczonym i zmarginalizowanym $w$ istniejących relacjach władzy. Wskazują, że nierówności są związane nie tylko z przynależnością rasową czy płciową, ale także gatunkową.

Posthumanizm proponuje myślenie w kategoriach kontinuum, a ludzie i zwierzęta stanowią jedynie pewne punkty na skali. „Zwierzęta” poddano dekonstrukcji, ujawniając procesy ideologiczne, historyczne, językowe i kulturowe, które wpływają na współczesny sposób ich rozumienia i relacje z nimi. W rezultacie:

[...] dekonstrukcja zwierząt ujawnia trwałe zatarcie granic między gatunkami oraz płynną naturę kategorii, takich jak „,zwierzę” i „człowiek”. Zwierzę-jako-takie jest chimerą, a chimery są rzeczywiste. Każda jednostka jest połączeniem człowieka, zwierzęcia i maszyny, przez co badanie relacji człowiek-zwierzę jest badaniem relacji hybrydowych ${ }^{25}$.

Podejście takie ma na celu zmianę antropocentrycznego myślenia o ludziach i zwierzętach jako oddzielnych kategoriach oraz wskazanie na ich niestabilność i wzajemne powiązania.

W posthumanistycznym ujęciu pytanie o zwierzęcość lub bycie człowiekiem nie jest postrzegane jako problem stabilnych, określonych bytów, lecz raczej jako dynamiczna relacja. Do jej opisania Donna Haraway używa takich pojęć, jak ,gatunki stowarzyszone” czy „strefy kontaktu”"26. Strefy kontaktu to przestrzenie, w których ludzie wchodzą w relacje z innymi gatunkami (zwierząt, roślin, czy nawet z technologiami albo sztuczną inteligencją), a dzięki takiemu spotkaniu pojawiają się nowe formy komunikacji oraz nowa jakość relacji. Haraway sugeruje, że dzięki spotkaniom „twarzą w twarz” z wielogatunkowymi innymi uczymy się bardziej harmonijnej koegzystencji. Wspólne istnienie, życie w bliskości, współpraca i uzupełnianie się przyczyniły się do powstania ludzkiej kultury w jej obecnej formie.

Haraway wymaga, aby traktować zwierzęta poważnie, a nie jedynie jako metafory czy punkt wyjścia do dalszych rozważań. Pisze: „Psy to nie surogat teorii; nie są tu tylko po to, żeby z nimi myśleć. Są po to, żeby z nimi żyć”27. Analiza relacji psów z ludźmi stanowi punkt wyjścia do rozważań o uniwer-

25 K. Shapiro, M. DeMello, op.cit., s. 312.

26 Zob. D. Haraway, When Species Meet, Minneapolis 2008.

27 D. Haraway, Companion Species Manifesto: Dogs, People and Significant Otherness, Chicago 2003, s. 5; polski przekład: eadem, Manifest gatunków stowarzyszonych, przeł. J. Bednarek [w:] Teorie wywrotowe. Antologia przektadów, red. A. Gajewska, Poznań 2012, s. 245. 
salnych koncepcjach. Haraway przekonuje, że traktując poważnie relację człowiek-pies, możemy nauczyć się etyki i polityki pielęgnowania znaczącej inności ${ }^{28}$. Obserwacja tej relacji prowadzi do rozpoznania skomplikowanej sieci połączeń między ludźmi a przedstawicielami innych gatunków.

Badania prowadzone w nurcie posthumanizmu koncentrują się raczej na analizach dyskursu i kulturowych reprezentacji, a rezygnują z empirycznych badań dotyczących zwierząt jako takich. Rodzi to niebezpieczeństwo, że materialne zwierzęta znikną z pola widzenia, zasłonięte lawiną słów. W „Zwrocie posthumanistycznym" najciekawsze w mojej opinii są perspektywy, które przyjmują jego krytyczne założenia, lecz usiłują badać realne zwierzęta i relacje, w jakie wchodzą one z ludźmi. Dwa podejścia: etnografia wielogatunkowa i krytyczne zwierzęce geografie wydają się szczególnie interesujące.

Etnografię wielogatunkową można zdefiniować jako ,etnograficzne badanie i pisanie dostrojone do życia pojawiającego się w ramach przemieszczającego się zbiorowiska istot żywych (agentive beings)"'29. Eben Kirksey i Stefan Helmreich zwracają uwagę na „zwrot gatunkowy” w ramach antropologii. Stworzenia

[...] wcześniej pojawiające się na marginesach antropologii - jako część krajobrazu, jako jedzenie dla ludzi czy symbole - stały się pierwszoplanowe w najnowszych badaniach etnograficznych. Zwierzęta, rośliny, grzyby i mikroby, wcześniej ograniczone w relacjach antropologicznych do sfery zoe lub „nagiego życia” - tego, które przeznaczone jest do zabicia - zaczęły się pojawiać wraz z ludźmi w sferze bios, obdarzone wyraźnie biograficznymi i politycznymi formami istnienia ${ }^{30}$.

Podejście owo zrywa z przekonaniem, że to, co „społeczne”, jest wyłącznie ludzkim tworem. Zwierzęta, rośliny i inne organizmy zostały włączone w zakres wspólnoty, dzięki czemu na nowo pojawiają się w polu zainteresowania badaczy kultury.

Krytyczne zwierzęce geografie (Critical Animal Geographies) to podejście nawiązujące do krytycznych studiów nad zwierzętami, które dodatkowo poddaje analizie przestrzenie i miejsca zamieszkiwane przez zwierzęta. Wiele z nich (klatki, zagrody, ciężarówki transportujące zwierzęta, przemysłowe hodowle) ma związek z procesem podporządkowywania sobie zwierząt przez

28 Ibidem, s. 3.

29 L. Ogden, B. Hall, K. Tanita, Animals, Plants, People and Things: A Review of Multi-species Ethnography, ,Environment and Society: Advances in Research” 2013, no. 4 (1), s. 6.

${ }^{30}$ E. Kirksey, S. Helmreich, The Emergence of Multispecies Ethnography, „Cultural Anthropology" 2010, no. 25 (4), s. 545. 
ludzi i sprawowaniem kontroli nad ich ciałami ${ }^{31}$. Pod uwagę bierze się bezpośrednie, ucieleśnione doświadczenie zwierząt. Jest ono istotne dla zrozumienia takich praktyk, jak udomowienie, życie w niewoli, a także cierpienia zwierząt na farmach przemysłowych czy podczas transportu do rzeźni. Podejście to poddaje krytycznej analizie oraz upolitycznia powiązania między ludźmi a zwierzętami, szczególną wagę przywiązując do nadużyć i relacji władzy, które zazwyczaj pozostają niezauważane ${ }^{32}$.

Krytyczne zwierzęce geografie stanowią „trzecią falę" ${ }^{33}$ zwierzęcych geografii. Zainteresowania ,pierwszej fali” ograniczały się do zoogeografii, migracji zwierząt oraz zamieszkiwanych przez nie terenów. „Druga fala” stanowiła odmianę ekologii kulturowej i zwracała uwagę przede wszystkim na wyobrażenia i praktyki związane z opozycją człowiek-zwierzę. Myślenie w kategoriach hierarchicznych opozycji przyczyniło się do traktowania zwierząt jako „obiektów naturalnych", oddzielonych i niezależnych od ludzkiego świata kultury. Kulturowe ekologie podkreślały znaczenie procesów udomowienia zwierząt dla tworzenia kultury, ich wpływ na życie ludzi oraz środowisko. Pomimo prób redefinicji podziału kultura-natura nie dostrzegano, że sam podział jest kulturowo konstruowany i podtrzymywany. „Trzecia fala” rozpoznaje podmiotowość zwierząt oraz zaprzecza istnieniu znaczących i fundamentalnych różnic między ludźmi a zwierzętami. Zwierzęta postrzegane są jako indywidualności obdarzone własnymi historiami i doświadczeniami, zdolne do społecznych interakcji. Różnią się one nie tylko przynależnością gatunkową, lecz także jednostkowymi doświadczeniami i cechami charakteru ${ }^{34}$.

Oba podejścia opierają się na metodach badawczych wywodzących się z etnografii czy antropologii i badają powiązania między ludźmi, zwierzętami i środowiskiem. Zwierzęta uznawane są za podmioty oddziałujące na życie społeczne, polityczne i kulturalne, a także na ekonomię oraz proces tworzenia wiedzy. Pod wpływem posthumanizmu oraz teorii feministycznej sprawczość zwierząt jest traktowana relacyjnie. Działają one w odniesieniu do innych organizmów, włączając w to ludzi. Perspektywa taka sprawia, że przedmiotem badań są wspólnie zamieszkiwane przestrzenie oraz tworzone tam relacje z innymi.

Studia wyrastające z refleksji posthumanistycznej poszukują hybryd, powiązań i zatartych, niejasnych granic, aby w tych obszarach prowadzić swoje badania. Przyjmują, że kultura i życie społeczne są współtworzone przez międzygatunkowe interakcje, które mogą, ale nie muszą, obejmować ludzi.

31 Critical Animal Geographies: Politics, Intersections, and Hierarchies in a Multispecies World, eds. K. Gillespie, R.-C. Collard, New York 2015, s. 5-6.

${ }^{32}$ Ibidem.

33 J. Urbanik, Placing Animals: An Introduction to the Geography of Human-Animal Relations, Lanham 2012.

34 Critical Animal Geographies..., s. 5-6. 
Uwaga przesuwa się z człowieka na powiązania, w których jest on jednym z elementów. Interakcje między ludźmi i istotami innymi niż ludzie wykraczają poza badanie relacji człowiek-zwierzę (czy animal studies), uwzględniając także takie byty, jak wirusy i bakterie.

\section{Ruch na rzecz praw zwierząt}

Pojawienie się animal studies po części łączy się z działaniami ruchu na rzecz praw zwierząt. Jego prekursorzy domagali się większego poszanowania dla praw i dobrostanu zwierząt. Niejednokrotnie wskazywali, że postrzeganie różnic gatunkowych jako radykalnej różnicy jest wyłącznie wyrazem gatunkowizmu (Peter Singer). Biorąc za punkt wyjścia zdolność do odczuwania bólu i cierpienia (Singer) czy posiadanie emocji i umiejętności społecznych podobnych do ludzi (Tom Regan), domagali się rewizji ludzkiej wyjątkowości oraz zrównania w prawach różnych gatunków. Postulaty te, wsparte badaniami dotyczącymi emocji i umiejętności poznawczych zwierząt (np. Marc Bekoff), zmuszają do włączenia innych gatunków do ludzkiej wspólnoty etycznej i przyznania im pewnych praw.

Pomimo znacznego wpływu ruchu na rzecz praw zwierząt na animal studies obecnie relacja między nimi jest dość skomplikowana. Animal studies, przejmując część postulatów i wartości ruchu, poszukują autonomii i własnego języka. Różnice dotyczą zarówno sposobu definiowania zwierząt oraz ich praw, jak i metod działania mających prowadzić do „wyzwolenia zwierząt” czy zmiany ich społecznego traktowania. Ruch na rzecz praw zwierząt krytykowany jest przez część badaczy, takich jak Matthew Calarco czy Lee Hall, m.in. za brak wiedzy na temat filozoficznych podstaw traktowania zwierząt, brak świadomości politycznej i polityczne wstecznictwo, zamknięcie się na inne punkty widzenia, strategie czy argumenty ${ }^{35}$. Pojawiają się argumenty, że przez swoje radykalne i nie zawsze legalne działania ruch osłabia społeczne poparcie dla kwestii zwierzęcej. Matthew Calarco sceptycznie podchodzi do polityki praw zwierzą ${ }^{36}$, która, jego zdaniem, skoncentrowana jest wokół pojęć tożsamości i podmiotowości, przez co powiela błędy antropocentryzmu. Samo pojęcie praw zwierząt pochodzi z odtwarzającej antropocentryzm tradycji humanizmu. Skupianie się wyłącznie na kwestiach praw zwierząt prowadzi natomiast do pomijania innych kwestii politycznych czy nierówności społecz-

35 E. Aaltola, The Philosophy behind the Movement: Animal Studies versus Animal Rights, ,Society and Animals” 2011, no. 19.

36 M. Calarco, Zoographies, New York 2008. 
nych. Przykładem mogą być działania organizacji PETA, która w swoich kampaniach na rzecz praw zwierząt wykorzystuje nagie, erotycznie dostępne ciała kobiet, powielając w ten sposób seksistowskie przekazy.

Lee Hall krytykuje z kolei militarne i nasycone przemocą metody (blokady, wykradanie zwierząt), jakimi posługują się aktywiści ${ }^{37}$. Zniechęcają one opinię publiczną do poważnego traktowania kwestii praw zwierząt. Dodatkowo aktywiści często odwołują się do argumentów dotyczących dobrostanu zwierząt, podkreślając cierpienie zwierząt zamiast ich godności. Podejście takie sugeruje, że problemem jest wyłącznie okrucieństwo wobec zwierząt, a nie wykorzystywanie ich w ogóle.

Shapiro i DeMello wyrażają obawę, że radykalne postulaty głoszone przez aktywistów oraz przedstawicieli krytycznych studiów nad zwierzętami mogą się przełożyć na negatywne postrzeganie wszelkich działań na rzecz praw zwierząt, w tym także badań nad relacjami człowiek-zwierzę ${ }^{38}$. Jednocześnie zauważają, że związki z ruchem na rzecz praw zwierząt mogą pomóc badaczom i badaczkom akademickim w tworzeniu rozwiązań przydatnych $\mathrm{w}$ walce z eksploatacją zwierząt.

Bez względu na stosunek do ruchu praw zwierząt badaczki i badacze starają się wykorzystywać swoją pozycję akademicką do podejmowania działań na rzecz zmiany statusu zwierząt $\mathrm{w}$ społeczeństwie. Zasiadają w komisjach etycznych opiniujących eksperymenty z wykorzystaniem zwierząt, zabierają głos w publicznych dyskusjach, wspierają swoją wiedzą organizacje prozwierzęce. Swą postawą potwierdzają, że wiedza akademicka nie może być tworzona w oderwaniu od praktyki społecznej. Pokazują też, że za pomocą wiedzy można na owe praktyki wpływać i nadawać im bardziej etyczny charakter.

\section{Podsumowanie}

Akademickie badania nad zwierzętami (także w Polsce) muszą się mierzyć się z kilkoma zagrożeniami. Po pierwsze, wiele analiz dotyczy tematów czy motywów zwierzęcych w literaturze, kulturze czy sztuce, lecz są one osadzone w antropocentrycznej perspektywie. Takie tematy, jak ,pies i jego pan” powtarzają kulturowe przekonania o podrzędności i zależności zwierząt. Pomijają ich sprawczość, podmiotowość czy godność i traktują je jak przedmiot czy narzędzie, którym manipuluje człowiek. Po drugie, zwrot ku posthumanizmowi powoduje, że znaczna część badań koncentruje się wyłącznie na analizie zwierząt jako kulturowych konstruktów. Sprawia to, że realne zwierzęta oraz stosowane wobec nich praktyki znikają z pola widzenia. Trzecim zagroże-

\footnotetext{
37 E. Aaltola, op.cit.

38 K. Shapiro, M. DeMello, op.cit.
} 
niem może być dążenie do neutralności i obiektywności badań prowadzonych w ramach akademii. W rezultacie stają się one abstrakcyjne i przestają wywierać jakikolwiek wpływ na praktyki społeczne. Wprawdzie zaangażowanie akademików w działania ruchu na rzecz praw zwierząt budzi kontrowersje, animal studies jednak podkreślają społeczną odpowiedzialność uniwersytetu, a zdecydowana większość badaczy dąży do tego, aby ich prace oddziaływały na sposób traktowania zwierząt i relacje między ludźmi a zwierzętami.

W studiach nad zwierzętami można zauważyć dwa równoległe trendy: badanie kulturowych reprezentacji zwierząt oraz badanie zwierząt jako takich (ucieleśnionych). $Z$ jednej strony krytyczna analiza społeczno-kulturowego procesu „tworzenia zwierzęcia” daje wgląd w przesłanki, które stoją za współczesnymi wyobrażeniami oraz wynikającymi z nich praktykami. Skupianie uwagi na zwierzętach jako na kulturowych reprezentacjach i symbolach wiąże się jednak z niebezpieczeństwem zapomnienia o realnych zwierzętach. Kontakt $\mathrm{z}$ reprezentacjami nie zastąpi kontaktu $\mathrm{z}$ ucieleśnionym zwierzęciem. $Z$ drugiej strony krytyczna analiza procesów „tworzenia zwierzęcości” w posthumanizmie sprawia, że badania rzeczywistych zwierząt muszą się mierzyć z nowymi problemami metodologicznymi. Zwierzę - naturalistycznie prosty przedmiot badania w naukach przyrodniczych - ulega problematyzacji. W związku z tym badania ucieleśnionych zwierząt stają się dużo bardziej krytyczne i refleksyjne. Badacze i badaczki świadomi są kulturowych procesów kształtujących metodologie, a także antropocentrycznej perspektywy, która zazwyczaj wywiera wpływ na badania. Podejmowane zostają zatem teoretyczne i metodologiczne próby zrozumienia innych sposobów doświadczania świata.

\section{Bibliografia}

Aaltola E., The Philosophy behind the Movement: Animal Studies versus Animal Rights, ,Society and Animals” 2011, no. 19.

Beck A., Katcher A., Between Pets and People: The Importance of Animal Companionship, Indiana 1996.

Benston K.W., Experimenting at the Threshold: Sacrifice, Anthropomorphism, and the Aims of (Critical) Animal Studies, „PMLA” 2009, no. 124 (2).

Best S., Nocella II A.J., Gigliotti C., Kemmerer L., Introducing Critical Animal Studies, „Journal for Critical Animal Studies” 2007, no. 5 (1).

Braidotti R., Po człowieku, przeł. J. Bednarek, A. Kowalczyk, Warszawa 2014.

Calarco M., Zoographies, New York 2008.

Critical Animal Geographies: Politics, Intersections, and Hierarchies in a Multispecies World, eds. K. Gillespie, R.-C. Collard, New York 2015. 
Hamilton L., Taylor N., Ethnography after Humanism: Power, Politics and Method in Multi-Species Research, London 2017.

Haraway D., Companion Species Manifesto: Dogs, People and Significant Otherness, Chicago 2003.

Haraway D., Manifest gatunków stowarzyszonych, przeł. J. Bednarek [w:] Teorie wywrotowe. Antologia przekładów, red. A. Gajewska, Poznań 2012.

Haraway D., When Species Meet, Minneapolis 2008.

Herzog H., Gender Differences in Human-Animal Interactions: A Review, „Anthrozoös" 2007, no. 20 (1).

Herzog H., Some We Love, Some We Hate, Some We Eat: Why It's So Hard to Think Straight About Animals, New York 2010.

Irvine L., If You Tame Me: Understanding our Connection with Animals, Philadelphia 2004.

Kirksey E., Helmreich S., The Emergence of Multispecies Ethnography, „Cultural Anthropology" 2010, no. 25 (4).

McCance D., Critical Animal Studies: An Introduction, Albany 2013.

McHugh S., One or Several Literary Animal Studies?, H-Animals, H-Net, 2006, https://networks.h-net.org/node/16560/pages/32231/one-or-several-literary-animal-studies-susan-mchugh [dostęp: 15.01.2018].

Ogden L., Hall B., Tanita K., Animals, Plants, People and Things: A Review of Multi-species Ethnography, „Environment and Society: Advances in Research” 2013, no. 4 (1).

Ritvo H., History and Animal Studies, „Society and Animals” 2002, no. 10 (4).

Sanders C., ,, The Dog You Deserve”: Ambivalence in the K-9 Officer/Patrol Dog Relationship, ,Journal of Contemporary Ethnography” 2006, no. 35 (2).

Serpell J., W towarzystwie zwierząt. Analiza zwiazków ludzie-zwierzęta, przeł. A. Alichniewicz, Warszawa 1999.

Shapiro K., The State of Human-Animal Studies: Solid, at the Margin!, „Society and Animals" 2002, no 10 (4).

Shapiro K., DeMello M., The State of Human-Animal Studies, „Society and Animals” 2010, no. 18 (3).

Taylor N., Humans, Animals, and Society: An Introduction to Human-Animal Studies, New York 2013.

Urbanik J., Placing Animals: An Introduction to the Geography of Human-Animal Relations, Lanham 2012.

White R., „Journal for Critical Animal Studies” 2010, http://www.criticalanimalstudies.org/?page_id=103 [dostęp: 15.01.2018].

Wolfe C., Animal studies, dyscyplinarność i post(humanizm), przeł. K. Krasuska, „Teksty Drugie” 2013, nr 1-2.

Wolfe C., Human, All too Human: „Animal Studies” and the Humanities, „PMLA” 2009, vol. 124, no. 2.

Wolfe C., Moving Forward, Kicking Back: The Animal Turn, „Postmedieval: A Journal of Medieval Cultural Studies" 2011, no. 2. 